\title{
ANALISIS DUKUNGAN INSTITUSI TERHADAP PENYELENGGARAAN KANTIN SEHAT PADA MAHASISWA DI UNIVERSITAS NEGERI DAN SWASTA DI JAKARTA
}

\author{
Tria Astika Endah Permatasari ${ }^{*}$, Nurkamalia ${ }^{2}$, Nia Mailan Astin ${ }^{3}$ \\ 1Program Studi Gizi, Fakutas Kedokteran dan Kesehatan, Universitas Muhammadiyah \\ Jakarta, Indonesia \\ 2,3Program Studi Kesehatan Masyarakat, Fakutas Kesehatan Masyarakat, Universitas \\ Muhammadiyah Jakarta, Indonesia \\ *Email : tria.astika@umj.ac.id
}

\begin{abstract}
ABSTRAK
Masalah gizi ganda terus meningkat di berbagai negara termasuk di Indonesia. Salah satu kelompok yang berkontribusi dalam kondisi ini adalah mahasiswa. Ketersediaan kantin sehat di kampus menjadi faktor penyebab utama rendahnya status gizi mahasiswa. Penelitian ini bertujuan untuk mengetahui dukungan institusi terhadap peyelenggaraan kantin sehat pada mahasiswa di Universitas negeri dan swasta di Jakarta. Penelitian ini menggunakan desain studi analitik observasional dengan menggunakan metode cross sectional. Subjek penelitian ini adalah mahasiwa Negeri dan mahasiswa Swasta di Jakarta. Teknik pengambilan sampel yang digunakan adalah accidental sampling dengan jumlah responden sebanyak 114 responden yang terdiri dari 57 mahasiswa Perguruan Tinggi Negeri dan 57 mahasiswa Perguruan Tinggi Swasta. Data diambil pada bulan Oktober-November 2017 dengan menggunakan kuesioner yang diadaptasi dari Ontario Society of Nutrition Professionals in Public Health (OSNPPH). Data ini dianalisis dengan menggunakan analisis multivariat logistic ganda. Penelitian ini menunjukkan bahwa didapatkan nilai OR pada dukungan institusi sebesar 4,246 (95\% CI: 1,933 - 9,326). Berdasarkan persepsi mahasiswa, dukungan institusi berpeluang 4 x lipat terhadap penyelenggaraan kantin sehat dibandingkan dengan yang tidak mendapatkan dukungan ististusi. Oleh karenanya, perlu adanya dukungan kebijakan penyelenggaraan kantin sehat dan penyediaan fasilitas di kampus dalam menunjang pemenuhan gizi mahasiswa.
\end{abstract}

Kata Kunci: penyelenggaraan kantin sehat, status gizi, mahasiswa

\section{ABSTRACT}

The problem of multiple nutrition continues to increase in various countries including Indonesia. One group that contributes to this condition is students. The availability of healthy canteens on campus is a major cause of the low nutritional status of students. This study aims to determine institutional support for the implementation of healthy canteens for students at public and private universities in Jakarta. This study uses an observational analytic study design using a cross sectional method. The subjects of this study were State students and Private students in Jakarta. The sampling technique used was accidental sampling with 114 respondents consisting of 57 State University students and 57 Private University students. Data were collected in October-November 2017 using a questionnaire adapted from the Ontario Society of Nutrition Professionals in Public Health (OSNPPH). This data was analyzed using multiple logistical multivariate analysis. This study shows that the OR value obtained in institutional support is 4,246 (95\% CI: 1,933 - 9,326). Based on students' perceptions, institutional support has a $4 x$ greater chance of organizing a healthy canteen compared to those not getting ististusi support. Therefore, there is a need for policy support for organizing a healthy canteen and providing facilities on campus to support the fulfillment of student nutrition.

Keywords: organizing a healthy canteen, nutrition status, students 


\section{PENDAHULUAN}

Salah satu masalah kesehatan yang berpengaruh terhadap kelangsungan dan peningkatan kualitas hidup masyarakat adalah masalah gizi. Pada saat ini, Indonesia mengalami beban gizi ganda, dimana masyarakat yang kurang gizi terus meningkat dan belum tertangani secara tuntas sementara itu, masyarakat dengan gizi lebih mulai meningkat. Munculnya masalah gizi lebih merupakan hasil dari berkembangnya ilmu gizi dan perubahan pola makan serta gaya hidup. Pada tahun 1980-an yang menyebabkan terjadinya transisi pola masalah gizi dari masalah gizi kurang ke masalah gizi lebih. Pada negara berkembang khususnya di Indonesia, masa trasisi ini disebut sebagai masalah gizi ganda. Keadaan ini akan lebih memperburuk kualitas sumber daya manusia bangsa Indonesia (Suharsa, Hari., Sahnaz. 2014, Permatasari, 2011).

Keberhasilan pembangunan nasional suatu bangsa ditentukan oleh ketersediaan sumber daya manusia (SDM) yang berkualitas, yaitu SDM yang memiliki fisik yang tangguh, mental yang kuat dan kesehatan yang prima di samping penguasaan terhadap ilmu pengetahuan dan teknologi. Kekurangan gizi dapat merusak kualitas SDM (Atmarita, Fallah, Tatang, 2014, Permatasari, 2012).

Rendahnya status gizi dan kesehatan pada usia dewasa awal berdampak terhadap terjadinya berbagai penyakit degeneratif. Salah satu kelompok dewasa awal adalah mahasiswa. Asupan makanan pada kelompok ini sangat ditentukan oleh ketersediaan makanan sehat di kantin yang tersedia di lingkungan kampus. Perbaikan gizi diperlukan pada seluruh siklus kehidupan, mulai sejak masa kehamilan, bayi dan anak balita, pra sekolah, anak SD dan MI, remaja dan dewasa awal sampai usia lanjut (Heath et al., 2005).

Mahasiswa pada umumnya setiap hari menghabiskan waktu setengah hari hingga satu hari penuh berada di lingkungan kampus, dengan aktivitas yang beragam.
Mahasiswa dengan beragam aktivitas tersebut membutuhkan pemenuhan gizi melalui makanan yang di konsumsinya. Pemenuhan konsumsi mahasiswa tidak selalu dipenuhi oleh penyelenggaraan makanan di rumah, sehingga untuk memenuhi kebutuhan makanannya mahasiswa memilih makanan di luar rumah dengan cara jajan di kantin, warung, kedai makanan atau kafetaria di sekitar lingkungan kampus (Nurhayati, 2012, Permatasari, 2019).

Salah satu komponen penting dalam melaksanakan usaha kesehatan sekolah yaitu melalui layanan kantin sehat. Kantin/kafetaria adalah suatu usaha (tempat) yang dilakukan sekolah untuk memberikan pelayanan kepada para siswa atau unsur sekolah lainnya yang membutuhkan makanan maupun minuman sehat sehingga kegiatan belajar mengajar di sekolah dapat mencapai tujuan secara maksimal. (Kusmintardjo, 1993:47).

Hasil penelitian tentang institusi pendidikan sehat yang memiliki kantin dilakukan oleh Pusat Pengembangan Kualitas Jasmani Depdiknas tahun 2007 pada 640 institusi pendidikan di provinsi yang diteliti di Indonesia didapatkan sebanyak $40 \%$ belum memiliki kantin. Sementara dari yang memiliki kantin $(60 \%)$ sebanyak $84,3 \%$ kantinnya belum memenuhi syarat kesehatan. (Suratmono, 2011).

Penyelenggara kantin sehat didukung oleh adanya kebijakan yang kuat di lingkungan kampus. Hal ini sangat dipengaruhi oleh Komitmen institusi, yaitu komitmen para pimpinan dan jajarannya serta pemangku kepentingan untuk menciptakan lingkungan kantin yang mendukung dan menumbuhkan budaya makan sehat. Unsur ini dapat dicapai melalui dukungan institusi, pembentukan komite kesehatan, menangani permasalahan di lingkungan kantin dan ketterlibatan langsung dengan mahasiswa. (OSNPPH, 2015). Faktor lainnya yang mempengaruhi tersedianya kantin sehat adalah pendekatan komite, area makan (indoor atau outdoor), peralatan, pengaturan kebijakan, dan 
penyelenggaraan makanan. (OSNPPH, 2015).

Salah satu komponen penting dalam melaksanakan usaha kesehatan sekolah yaitu melalui layanan kantin sehat. Mengingat peranan kantin yang penting, pihak institusi seharusnya memberikan perhatian pada pengelolaan kantin. Berdasarkan fenomena yang terjadi maka peneliti tertarik untuk menganalisis faktor apa saja yang berpengaruh terhadap penyelenggaraan kantin sehat di Universitas Negeri dan Swasta.

\section{METODE PENELITIAN}

\section{Jenis dan Desain Penelitian}

Penelitian ini menggunakan desain studi analitik observasional dengan menggunakan metode cross sectional dengan tujuan untuk menganalisis faktor apa saja yang berpengaruh terhadap penyelenggara makanan sehat di kantin Universitas Negeri dan Swasta.

\section{Tempat dan Waktu}

Penelitian ini dilakukan di Jakarta tepatnya di Universitas Muhammadiyah Jakarta dan Universitas Islam Negeri Syarif Hidayatullah. Penelitian ini dilakukan selama 2 bulan, yaitu pada Oktober November tahun 2017 dengan menggunakan kuesioner yang diadaptasi dari Ontario Society of Nutrition Professionals in Public Health (OSNPPH).

\section{Alat dan Bahan yang digunakan}

Alat ukur dan bahan yang digunakan dalam penelitian ini adalah lembar pernyataan sebelum persetujuan (PSP), lembar kesediaan pengisian kuesioner atau informed consent, pertanyaan yang berkaitan dengan penelitian yang diadaptasi dari dari Ontario Society of Nutrition Professionals in Public Health (OSNPPH), timbangan berat badan, alat pengukur tinggi badan (mikrotoise).

\section{Metode Pengumpulan Data}

Pengumpulan data ini dilakukan sendiri oleh peneliti. Tahap pengumpulan data yang dilakukan oleh peneliti, yaitu:

\section{Persiapan}

Pada tahap ini, peneliti menyusun proposal penelitian yang akan dijadikan dasar atau acuan oleh peneliti terhadap penelitian yang dilakukannya. Pada tahap ini, peneliti juga mempersiapkan kuesioner yang akan dibagikan kepada responden sesuai dengan jumlah responden yang telah dihitung/ditetapkan. Kuesioner tersebut terdiri dari lembar penjelasan, lembar persetujuan menjadi responden penelitian, dan lembar pertanyaan.

\section{Pelaksanaan}

Setelah tahap persiapan selesai, maka peneliti melakukan tahap pelaksanaan. Pengumpulan data ini dilakukan pada minggu kedua bulan November 2017. Pada tahap ini, peneliti mengambil data primer yang berasal dari kuesioner yang dibagikan kepada mahasiswa di Universitas Negeri dan Swasta yang kami tuju. Sebelum membagikan kuesioner, peneliti menjelaskan maksud, manfaat, dan tujuan dari penelitiannya tersebut kepada responden, setelah melakukan penjelasan dan responden mengerti terhadap apa yang dijelaskan oleh peneliti, maka peneliti meminta responden untuk mengisi lembar persetujuan untuk menjadi responden, setelah itu peneliti memberikan lembar kuesioner yang berisi pertanyaan, memberikan arahan bagaimana mengisi kuesioner tersebut dan meminta responden untuk teliti dan jujur dalam mengisi kuesioner yang telah diberikan. Setelah responden mengumpulkan kuesioner yang telah diisi, peneliti memastikan terlebih dahulu bahwa kuesioner yang diisi telah diisi secara lengkap. Setelah tahap pengumpulan data primer selesai, maka peneliti melakukan tahap pengolahan data yang terdiri dari editing, coding, data entry atau processing, tabulasi, dan analisis data yang dilakukan pada minggu ke-4 bulan 
November 2017 - minggu pertama bulan Desember 2017.

\section{Metode Pengolahan Data}

Untuk memperoleh penyajian data sebagai hasil yang berarti dan kesimpulan yang baik, diperlukan pengolahan data. Sebelumnya di lakukan uji normalitas data dengan menggunakan Kolmogorov Smirnov Test, apabila data berdistribusi normal maka uji hipotesis statistik yang digunakan adalah uji Chi Square. Data yang telah diperoleh dari proses pengumpulan data akan diubah kedalam bentuk tabel, kemudian data diolah menggunakan program SPSS 2013 for Windows dengan nilai $a=0,05$, Kemudian proses pengolahan data menggunakan program komputer ini terdiri beberapa langkah :

a. Editing Data, data yang telah diperoleh diperiksa terlebih dahulu. Pemeriksaan ini untuk melihat kelengkapan pengisian, kesinambungan, dak keseragaman data.

b. Coding, untuk memberikan kode pada jawaban dari pertanyaan kuesioner, hal ini dimaksudkan untuk memudahkan dalam analisis.

c. Data entry, memasukkan data kedalam komputer.

d. Verifikasi, memasukkan data pemeriksaan secara visual terhadap data yang telah dimasukkan kedalam komputer.

e. Tabulasi Data, data yang telah terkumpul dalam komputer lalu akan penulis analisis berupa tampilan-tampilan tabel distribusi frekuensi dan narasi.

\section{Teknik Analisis Data}

Dalam penelitian ini digunakan teknik analisis data, yaitu analisis univariat, bivariat, dan multivariat. Analisis univariat digunakan untuk mendekskripsikan variabel dukungan institusi, pendekatan komite, area makan (indoor atau outdoor), peralatan, dan pengaturan kebijakan yang disajikan dalam bentuk tabel distribusi frekuensi dan persentase dari setiap variabelnya. Selanjutnya, penelitian ini menggunakan analisis bivariat untuk mencari hubungan variabel bebas dan variabel terikat dengan uji statistik yang disesuaikan dengan skala data yang ada. Taraf siginifikasi yang digunakan adalah 95\% dengan nilai kemungkinan 5\%. Selain itu, penelitian ini menggunakan analisis multivariat untuk menganalisis faktor dominan yang berpengaruh terhadap variabel dependent.

\section{HASIL DAN PEMBAHASAN}

\section{Analisis Univariat}

Berdasarkan hasil analisis univariat, dari 114 mahasiswa dan mahasiswi yang menjadi responden didapatkan sebanyak 55,3\% responden yang menyatakan bahwa penyelenggaraan makanan sehat di kantin kampusnya belum optimal. Sedangkan sebanyak 58,8\% responden menilai tersedianya area makan (indoor atau outdoor) yang nyaman di kantin kampus.

Mahasiswa yang menilai dalam keadaan baik penyelenggaraan makanan sehat di kantinnya adalah sebanyak 54,4\%. Jika dilihat dari pendekatan komite maka didapatkan sebanyak $46,5 \%$ responden yang menilai baik, sebanyak $44,7 \%$ responden yang menilai terdapat pengaturan kebijakan dan sebanyak $36,8 \%$ responden menilai bahwa peralatan yang ada di kantin kampus dalam keadaan baik, hasil analisis data ini dapat dilihat pada Tabel 1 . 
Tabel 1. Hasil Analisis Univariat Penyelenggaraan Makanan Sehat dan Variabel Lainnya

\begin{tabular}{lcc}
\hline Variabel & Frekuensi & $\%$ \\
\hline Penyelenggaraan Makanan & & \\
\hline Ya, terselenggara. & 63 & 55,3 \\
Tidak terselenggara. & 51 & 44,7 \\
Jumlah & 114 & 100 \\
\hline Dukungan Institusi & & \\
\hline Ya, didukung. & 62 & 54.4 \\
Tidak didukung. & 52 & 45.6 \\
Jumlah & 114 & 100 \\
\hline Pendekatan Komite & & \\
\hline Ya, dilakukan. & 53 & 46.5 \\
Tidak dilakukan. & 61 & 53.3 \\
Jumlah & 114 & 100 \\
\hline Area makan & & \\
(indoor atau outdoor) & & 58.8 \\
\hline Ya, tersedia. & 67 & 41.2 \\
Tidak tersedia. & 47 & 100 \\
Jumlah & 114 & \\
\hline Peralatan & & \\
\hline Ya, tersedia. & 42 \\
Tidak tersedia. & 72 & 63.2 \\
Jumlah & 114 & 100 \\
\hline Pengaturan Kebijakan & & \\
\hline Ya, terdapat pengaturan. & 51 & 100 \\
Tidak terdapa pengaturan. & 63 & \\
Jumlah & 114 & \\
\hline
\end{tabular}

Tabel 2. Hasil analisis seleksi kandidat sebelum tahapan pemodelan multivariat

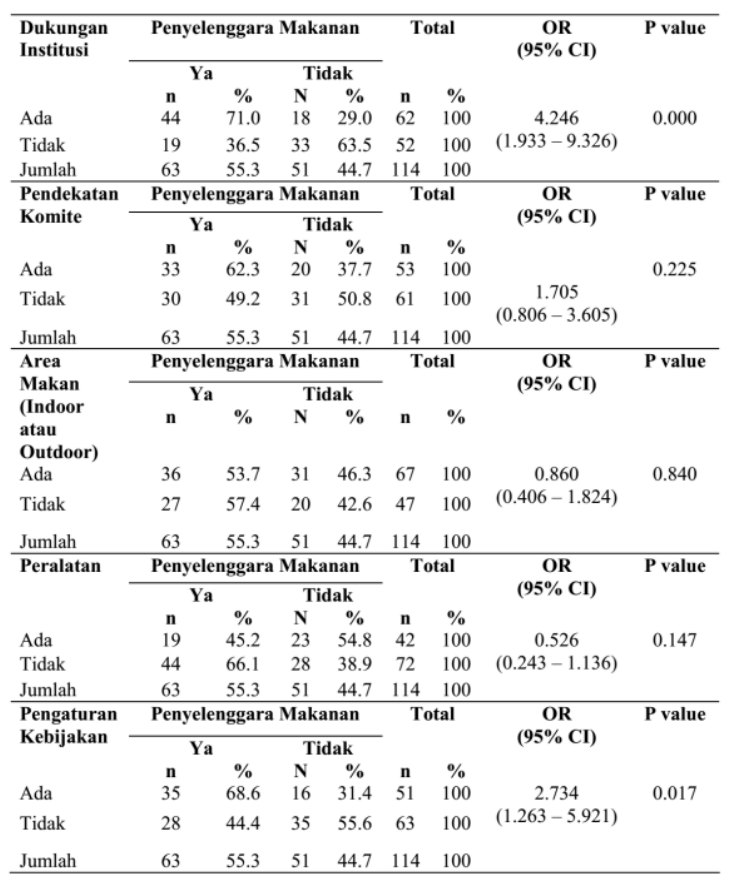

Berdasarkan Tabel 2, untuk tahapan seleksi kandidat dilakukan dengan analisis bivariat menggunakan uji chi-square. Dari 5 variabel yang dianalisis, dapat diketahui bahwa terdapat 4 (empat) variabel yang lolos seleksi kandidat dengan nilai $\mathrm{p}<0.25$ yaitu variabel dukungan institusi, pendekatan komite, peralatan, dan pengaturan kebijakan. Hasil analisis pada tahapan pemodelan akhir multivariat dapat diketahui bahwa dukungan isntitusi merupakan variabel paling dominan yang berpengaruh terhadap penyelengaraan makanan di kantin Universitas Negeri dan Swasta sebesar 4,246 (95\% CI: 1,933 - 9,326) dapat dilihat pada Tabel 3.

Tabel 3. Hasil akhir pemodelan pada analisis multivariat

\begin{tabular}{lccccc}
\hline Variabel & B & Sig & Exp (B) & \multicolumn{2}{c}{$\begin{array}{c}\text { OR } \\
(\mathbf{9 5 \%} \text { CI) }\end{array}$} \\
\cline { 3 - 5 } & & & & Lower & Upper \\
\hline $\begin{array}{l}\text { Dukungan } \\
\text { Institusi }\end{array}$ & 1,446 & 0,000 & 4,246 & 1,933 & 9,326 \\
& & & & & \\
\end{tabular}

Berdasarkan hasil penelitian ini dapat disimpulkan bahwa adanya dukungan institusi berpeluang 4 kali lebih besar dalam penyelengaraan makanan sehat dibandingkan dengan yang tidak mendapatkan dukungan dari institusi. Hasil ini sejalan dengan penelitian yang dilakukan oleh Milder, et al (2015) bahwa institusi yang berpartisipasi dalam penyelenggaraan makanan sehat secara signifikan $(P<0,001)$ lebih banyak daripada institusi yang tidak berpartisipasi. Kemudian, penelitian yang dilakukan oleh Raulio, et al (2010) menunjukkan bahwa institusi yang memberikan dukungan cenderung lebih dapat menyelenggarakan makanan sehat dengan baik daripada institusi yang tidak memberikan dukungan.

Menurut OSNPPH (2015) dukungan institusi dapat berupa pembentukan komite kesehatan, menangani permasalahan di lingkungan kantin dan terlibat langsung dengan mahasiswa, hal tersebut mendukung penyelengaraan kantin sehat di kantin Universitas Negeri dan Swasta. Peran institusi dalam hal ini adalah untuk menciptakan lingkungan kantin yang mendukung dan menumbuhkan budaya makan sehat. Institusi tersebut dapat membuat dukungan komitmen untuk 
makan sehat yang dituangkan dalam visi dan misi di institusinya.

\section{KESIMPULAN}

Berdasarkan hasil penelitian yang dilakukan dapat dibuat kesimpulan sebagai berikut: Penyelenggaraan makanan pada penelitian ini menunjukkan hasil sebanyak 55,3\% mahasiswa menilai bahwa penyelenggaraan makanan sehat di kantin kampus belum optimal. Dari 57 mahasiswa di Universitas Swasta terdapat 56,4\% yang menilai penyelenggaraan kantin kurang optimal, dan dari 57 mahasiswa di Universitas Negeri terdapat $54,2 \%$ yang menilai hal serupa. Penelitian ini menggunakan 5 variabel independent yang dianalisis, dapat diketahui bahwa terdapat 4 (empat) variabel yang lolos seleksi kandidat dengan nilai $\mathrm{p}<$ 0,25 yaitu variabel dukungan institusi, pendekatan komite, peralatan, dan pengaturan kebijakan. Berdasarkan persepsi mahasiswa, dukungan institusi berpeluang 4 $x$ lipat terhadap penyelenggaraan kantin sehat dibandingkan dengan yang tidak mendapatkan dukungan institusi sebesar 4,246 (95\% CI : 1,933 - 9,326).

\section{UCAPAN TERIMA KASIH}

Terimaksih kepada Universitas Muhammadiyah Jakarta dan tim penelitian yang bekerjasama sehingga dapat dilakukan penelitian ini.

\section{DAFTAR PUSTAKA}

Atmarita, Fallah, Tatang. 2004. Analisis Status Gizi Dan Kesehatan Masyarakat. 2004. (online) http://sdmuhcc.net/elearning/aridat a_web/how / k/kesehatan/4_analisis gizi.pdf

[Depkes RI] Departemen Kesehatan RI. 2013. Pedoman Pelayanan Gizi Rumah Sakit. Ditjen Bina Kesehatan Masyarakat, Jakarta.

Heath., Deanne, L. and Panaretto, S.K. 2005. Original Article Nutrition Status of Primary School Children in Townsville. Aust. J. Rural Health, 13: 282-289.
Kusmintardjo. 1993. Pengelolaan Layanan Khusus di Sekolah (Jilid II). Malang: IKIP Malang.

Melder, et al. 2015. Food Suply and Actions to Improve Dietary Behavioyr of Students. A comparison between secondary schools participating or not participating in the "Healthy School Canteen Program". Public Health Nutrition: Cambridge Vol. 18 Iss 2. (Feb 2015).

Nurhayati, A.I., E Lasmanawati., C Yulia. 2012. Pengaruh Mata Kuliah Berbasis Gizi Pada Pemilihan Makanan Jajanan Mahasiswa Program Studi Pendidikan Tata Boga. FPTK: Universitas Pendidikan Indonesia.

Oktaviani RW \& Suryana RN. 2005. Analisis kepuasan pengunjung dan pengembangan fasilitas wisata agro. Jurnal Agro Ekonomi, 24(1), 41-58.

Ontario Society of Nutrition Professionals in Public Health (OSNPPH). 2015.

Permatasari, T. A. (2011). Hubungan asupan kalsium dan faktor risiko lainnya dengan kejadian osteoporosis pada kelompok dewasa awal di wilayah Ciputat-Tangerang Selatan. Universitas Diponegoro, Semarang.

Permatasari, T. A. E. (2012). Istimewakah air susu ibu secara islam dan kesehatan. Jurnal Kedokteran dan Kesehatan, 8(1), 55-68.

Permatasari, T. A. E., Chairunnisa, C., \& Herlina, L. (2019). Penguatan Kapasitas Kader Melalui Gerakan 'Aisyiyah Sehat (Grass) Sebagai Upaya Pencegahan Penyakit Tidak Menular Dan Stunting, Serta Peningkatan Kesehatan Ibu Dan Anak Di Provinsi Kalimantan Tengah. In Prosiding Seminar Nasional Pengabdian Masyarakat LPPM UMJ.

Raulio, et al. 2010. School and Workplace Meals Promote Healthy Food Habits. Publis Health Nutrition and Health in Finland : Cambridge Vol. 13 Iss 6A (June 2010).

Suharsa, Hari., Sahnaz. 2014. Status Gizi Lebih dan Faktor-faktor lain yang 
Berhubungan pada Siswa Sekolah Dasar Islam Tirtayasa Kelas IV dan V di Kota Serang Tahun 2014. Fakultas Ilmu Kesehatan Universitas Mathlaul Anwar (online) http://juliwi.com/published/E0301/J uliwi0301_53-76.pdf

Sukardi \& Chandrawatisma C. 2008. Analisis tingkat kepuasan pelanggan terhadap produk Corned Pronas produksi PT Cip Denpasar. Jurnal Teknik Industri Pertanian, 18(2), 106-117.

Suratmono. 2011. Pengawasan Keamanan Pangan Jajanan Anak Sekolah. Seminar
Keamanan Pangan dan Konsumsi pada Anak dalam Rangka Fonterra Nutriton Day, Jakarta, 5 Oktober 2011.

Suteki, Mega. 2014. Pelaksanaan Layanan Khusus Kantin di SMP Negeri 1 Diwek Jombang. Jurnal Inspirasi Manajemen Pendidikan. Vol. 4 No. 4 (April 2014) hl. 1-7.

Tjahyadi. (2006). Brand Trust dalam Konteks Loyalitas Merek: Peran Karakteristik Merek, Karakter istik Perusahaan dan Karakteristik Merek Pelanggan. Jurnal Manajemen, 6(1), 65-75. 
IAKMI Jurnal Kesehatan Masyarakat Indonesia, Volume 1, No. 1, April 2020

Journal Homepage : http://jurnal.iakmi.id/index.php/IJKMI

ISSN 2721-9437 (Media Online) 